\title{
Phytoplankton ecology of Lake Kivu (eastern Africa): biomass, production and elemental ratios
}

\author{
Hugo Sarmento, Mwapu Isumbisho, Stéphane Stenuite, François Darchambeau, Bruno Leporcq \\ and Jean-Pierre Descy
}

\section{Introduction}

Lake Kivu, located between Rwanda and the Kivu Province (Democratic Republic of Congo), is the smallest of the East African Great Lakes. It is a deep (max. 489 m), meromictic lake, with an oxic mixolimnion up to $60 \mathrm{~m}$, and a deep monimolimnion rich in dissolved gases, particularly methane (TIETZE et al. 1980, SCHMid et al. 2005). It is also the sole natural lake in which Limnothrissa miodon Boulenger, an endemic sardine from Lake Tanganyika, was introduced to fill an empty niche (Collart 1954, Simberloff 1995). Indeed, prior to the introduction, no planktivorous fish was present in the pelagic waters of Lake Kivu.

Recent studies have confirmed the oligotrophic status of Lake Kivu: with an annual average chlorophyll $a$ in the mixed layer of $2.2 \mathrm{mg} \mathrm{m}^{-3}$ and low nutrient levels in the euphotic zone, it combines a relatively shallow euphotic layer ( $\sim 18 \mathrm{~m})$, usually smaller than its mixed layer $(20-60 \mathrm{~m})$, with a weak thermal gradient in the mixolimnion (Isumbisho et al. 2006, SARMento et al. 2006). The most common phytoplankton species are the pennate diatoms Nitzschia bacata Hust. and Fragilaria danica (Kütz.) Lange-Bert., and the cyanobacteria Planktolyngbya limnetica (Lemm.) Komárková-Legnerová and Cronberg, and Synechococcus sp. (SARmento et al. 2006, 2007, 2008).

A survey in Lake Kivu covering the vertical and temporal variations of phytoplankton was carried out during 2003-2005, with a large number of plankton primary production measurements and assessment of phytoplankton nutritional status by seston $\mathrm{C}: \mathrm{N}: \mathrm{P}$ ratios.

Key words: East African Great Lakes, Lake Kivu, large lake, primary production, phytoplankton, stoichiometry, tropical and oligotrophic lake

\section{Material and methods}

Water samples were collected at Ishungu pelagic station (Southern basin) twice a month from January 2003 to June 2005 at 10 -m intervals in the $0-100 \mathrm{~m}$ water column using a 6-L Van Dorn bottle. For each sampling depth, $3 \mathrm{~L}$ of water were fil- tered on GF/F and immediately frozen for high-performance liquid chromatography (HPLC) pigment analysis. Three L of water from a pool of the upper $20 \mathrm{~m}$ of the water column were also filtered on pre-ignited GF/F filters for elemental carbon (C), nitrogen $(\mathrm{N})$ and phosphorus $(\mathrm{P})$ analysis. Chlorophyll $a$ $(\mathrm{Chl} a$ ) and biomass of the different algal groups was achieved by HPLC pigment analysis and CHEMTAX treatment as described in SARMENTO et al. (2006)

Primary production rate was determined in 21 field incubations $\left({ }^{14} \mathrm{C}\right.$ incorporation following STEEMAN-Nielsen 1952). Twelve supplementary incubations were made during the study period in pelagic stations of North, West, and East basins of Lake Kivu. Eighteen 120-mL glass bottles filled with water from a pooled mixolimnion sample were incubated with $\mathrm{NaH}-$ ${ }^{14} \mathrm{CO}_{3}$ in situ just below the surface. Duplicate sets of bottles were placed in a 9-case incubator at mid-day for $1.5 \mathrm{~h}$, providing a range from $0-60 \%$ of natural light energy. Radioactivity was measured using a Beckman scintillation counter (LS 6000 SC) with Filter-Count (Packard) as scintillation cocktail and the external standard method for quench correction. Photosynthesis parameters were determined following VolLENWEIDER's (1974) equation. Vertical light attenuation coefficient was estimated by Secchi disk disappearance depth and subsurface and submersible quantum Li-Cor sensors. Irradiance was measured throughout the study period using a Davis Weather Wizard III station light sensor (Davis Inotek Instruments, Baltimore, USA) located in the city of Bukavu. Those data were converted to PAR using a correction factor determined by comparison with several Li-Cor sensor irradiance measurements. Daily depth-integrated primary production $\left(\mathrm{g} \mathrm{C} \mathrm{m}^{-2} \mathrm{~d}^{-1}\right)$ was calculated using photosynthesis parameters, continuous surface irradiance data, and vertical light attenuation (KIRK 1983). Annual primary production $\left(\mathrm{g} \mathrm{C} \mathrm{m}^{-2} \mathrm{y}^{-1}\right)$ was estimated by multiplying the mean daily primary production by 365 .

Particulate $\mathrm{C}$ and $\mathrm{N}$ were analyzed in 41 integrated samples from the upper $20 \mathrm{~m}$ of the water column, using a Carlo-Erba NA1500 elemental analyzer. Particulate P was analyzed by spectrophotometric determination of phosphate after digestion with potassium persulphate and boric acid (VALDERRAMA 1981). The elemental ratios were expressed as the mean ratio in molar units of the different sampling dates. 


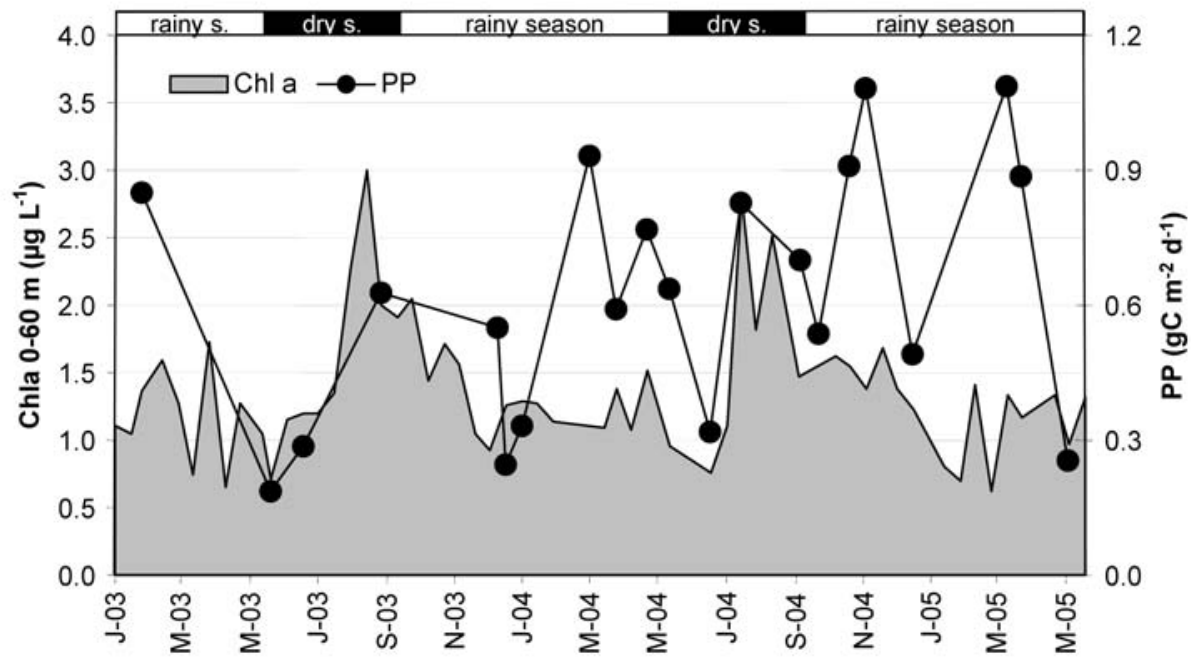

Fig. 1. Chlorophyll $a$ (shadded area) and primary production (dots) in the Southern basin of Lake Kivu (20032005), with indication of the rainy and dry seasons.

\section{Results and discussion}

In the upper $60 \mathrm{~m}$ of the water column (roughly corresponding to the maximal mixolimnion depth), Chl $a$ ranged between 0.63 and $3.00 \mathrm{mg} \mathrm{m}^{-3}$ (average $1.37 \mathrm{mg}$ $\mathrm{m}^{-3}$; Fig. 1). Considering only the top $20 \mathrm{~m}$ (roughly corresponding to the euphotic layer), the mean $\mathrm{Chl} a$ was $2.12 \mathrm{mg} \mathrm{m}^{-3}$ (range $1.03-4.55 \mathrm{mg} \mathrm{m}^{-3}$ ). Diatoms were the dominant group in the lake, particularly during the dry season episodes of deep mixing. During the rainy season, the stratified water column, with high light and lower nutrient availability, favored dominance of cyanobacteria, as discussed in SARMENTO et al. (2006).

The mean values of the photosynthetic parameters for the estimation of primary production were $3.51 \mu \mathrm{g} \mathrm{C} \mu \mathrm{g}$ $\mathrm{Chla}^{-1} \mathrm{~h}^{-1}$ for the $\mathrm{P}^{\mathrm{B}} \max$ and $285 \mu \mathrm{E} \mathrm{m}^{-2} \mathrm{~s}^{-1}$ for the Ik at Ishungu station. These values were obtained from 21 incubations distributed along the study period (Fig. 1). Mean daily primary production estimated from our measurements was $0.62 \mathrm{~g} \mathrm{C} \mathrm{m}^{-2} \mathrm{~d}^{-1}$ (corresponding to 228 $\mathrm{g} \mathrm{C} \mathrm{m}^{-2} \mathrm{y}^{-1}$ ), in a range of 0.19-1.09 $\mathrm{g} \mathrm{C} \mathrm{m}^{-2} \mathrm{~d}^{-1}$. Twelve supplementary incubations made in West, East, and North basins indicated a mean primary production around
$0.90 \mathrm{~g} \mathrm{C} \mathrm{m}^{-2} \mathrm{~d}^{-1}(0.51-1.43)$. These values do not seem substantially different from similar measurements made in the past (1.03-1.44 $\mathrm{g} \mathrm{C} \mathrm{m}^{-2} \mathrm{~d}^{-1}$ by Degens et al. 1973; $0.66-1.03 \mathrm{~g} \mathrm{C} \mathrm{m}^{-2} \mathrm{~d}^{-1}$ by JanNasch $1975 ; 0.33 \mathrm{~g} \mathrm{C} \mathrm{m}^{-2} \mathrm{~d}^{-1}$ by DesCy 1990).

Comparing these values with other numbers found in the literature for other East African Great Lakes, it seems that primary production in Lake Kivu is higher than in lakes Tanganyika or Malawi (Table 1), but not as high as we could expect from the differences observed in algal biomass. Chlorophyll $a$ in Lake Kivu $\left(2.12 \mathrm{mg} \mathrm{m}^{-3}\right)$ is 3 times higher than that of Lake Tanganyika $\left(0.70 \mathrm{mg} \mathrm{m}^{-3}\right.$ from DESCY et al. 2005), and almost 2 times higher than that of Lake Malawi $\left(1.40 \mathrm{mg} \mathrm{m}^{-3}\right.$ from GUILDFORD \& Hecky 2000). Primary production in Lake Kivu is, on average, only 1.5 times higher than that of Lake Tanganyika, and 1.35 higher than that of Lake Malawi (Table 1). This suggests some differences in terms of trophic structure between these lakes (discussed later in this section) that affect the fate of phytoplankton biomass.

Following elemental thresholds defined in the literature (Healey 1975, GuildFord et al. 2003), the sestonic C: $\mathrm{N}: \mathrm{P}$ ratios clearly indicated a moderate $\mathrm{N}$-limitation and a

Table 1. Mean annual phytoplantonic primary production $\left(\mathrm{gC} \cdot \mathrm{m}^{-2} \cdot \mathrm{y}^{-1}\right)$ in the East African Great Lakes.

\begin{tabular}{lll}
\hline & Mean primary production $\left(\mathrm{gC} \cdot \mathrm{m}^{-2} \cdot \mathrm{y}^{-1}\right)$ & Reference \\
\hline $\begin{array}{l}\text { L. Kivu (2003-2005) } \\
\begin{array}{l}\text { L. Tanganyika (2002-2003) } \\
\text { off Kigoma }\end{array}\end{array}$ & 228 & this study \\
$\begin{array}{l}\text { off Mpulungu } \\
\begin{array}{l}\text { L. Malawi (90's) } \\
\text { pelagic (south) }\end{array}\end{array}$ & 127 & STENUITE et al. 2007 \\
$\begin{array}{l}\text { L. Victoria (2001/2002) } \\
\text { lake-wide averages }\end{array}$ & 190 & STENUITE et al. 2007 \\
\hline
\end{tabular}


Fig. 2. Chlorophyll $a$ (shadded area) and elemental seston C:N, C:P and N:P ratios (dots) in the Southern basin of Lake Kivu (2003-2005), with indication of the rainy and dry seasons.
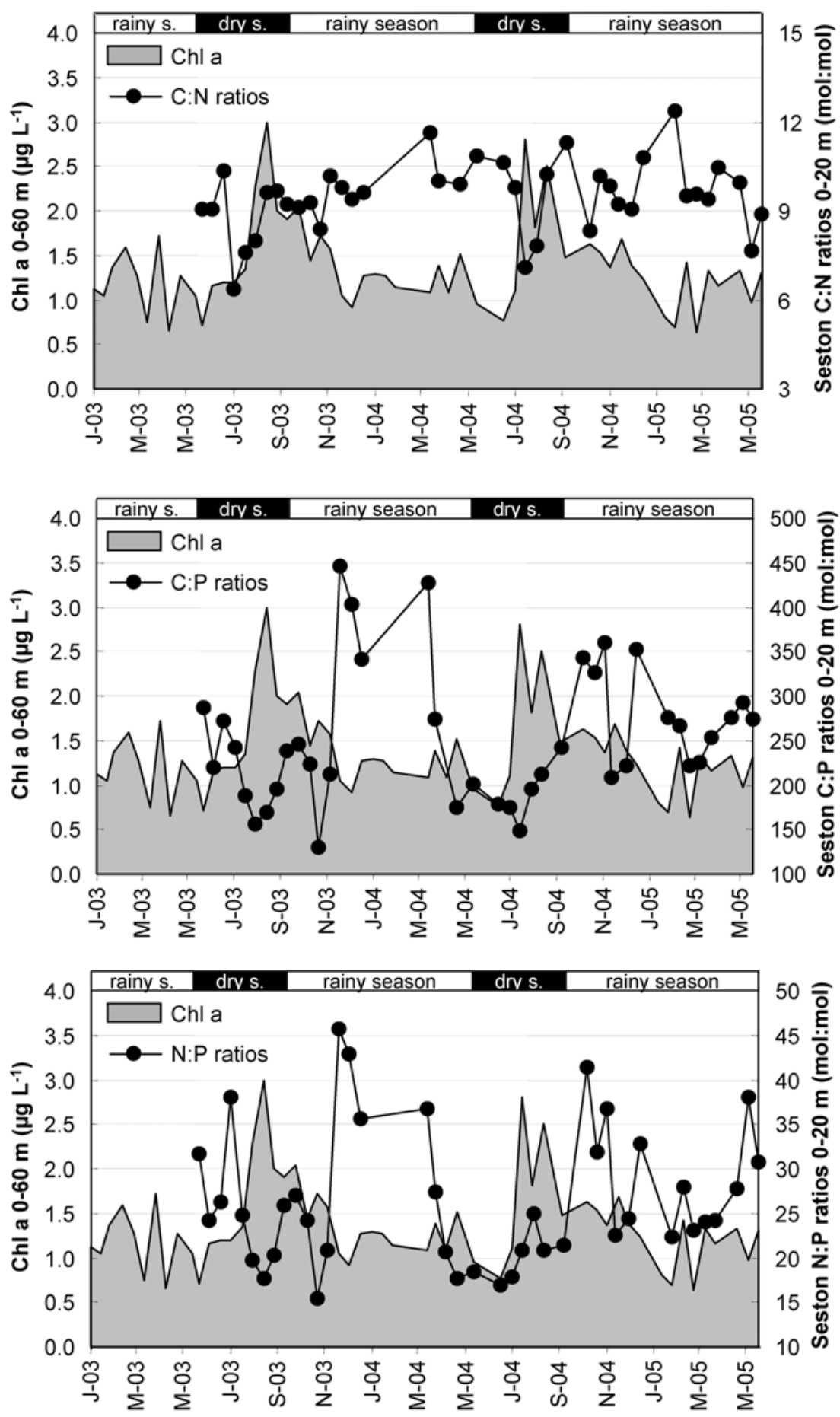

severe P-limitation, specially during part of the rainy seasons (Fig. 2). The comparison of these values with those found in the literature (Table 2) for the other East African Great Lakes indicates a stronger nutrient limitation in Lake Kivu. The relatively high C:P and N:P ratios point to co-limitation by $\mathrm{N}$ and $\mathrm{P}$.
Combined, this information suggests that $\mathrm{P}$ demand by the relatively abundant phytoplankton in Lake Kivu is often in excess of P supply to the epilimnion. Parallel studies (IsumBisHo et al. 2006) have suggested a low efficiency of trophic transfer at the phytoplankton-zooplankton interface. Part of the explanation may be that a 
Table 2. Elemental C:N:P ratios and $\mathrm{Chl} a$ in the East African Great Lakes (average values with reference to standard deviation).

\begin{tabular}{llllll}
\hline & $\mathrm{C}: \mathrm{P}$ & $\mathrm{C}: \mathrm{N}$ & $\mathrm{N}: \mathrm{P}$ & $\mathrm{Chl} a$ & Reference \\
\hline L. Kivu & 256.3 & 9.6 & 26.8 & 2.20 & this study \\
& $( \pm 75.1)$ & $( \pm 1.1)$ & $( \pm 7.7)$ & $( \pm 0.74)$ & \\
L. Tanganyika & 170.8 & 8.1 & 21.2 & 0.67 & STENUITE et al. 2007 \\
& $( \pm 43.3)$ & $( \pm 1.1)$ & $( \pm 5.3)$ & $( \pm 0.25)$ & \\
L. Malawi & 244.3 & 12.5 & 19.4 & 1.40 & GuILDFORD \& HECKY 2000 \\
& $( \pm 154.4)$ & $( \pm 3.6)$ & $( \pm 8.8)$ & $( \pm 2.00)$ & \\
L. Victoria & 148.5 & 8.2 & 18.3 & 26.50 & GuILDFORD \& HECKY 2000 \\
& $( \pm 76.4)$ & $( \pm 1.7)$ & $( \pm 7.6)$ & $( \pm 15.90)$ & \\
\hline
\end{tabular}

significant part of the phytoplankton biomass (more details on algal biomass and composition in SARMENTO et al. 2006, 2007) is inedible for metazooplankton. Moreover, the zooplankton study by IsumBisho et al. (2006) showed that current mesozooplankton biomass in Lake Kivu is much lower than in lakes Tanganyika and Malawi. Mesozooplankton structure is also different: it comprises 3 species of cyclopoid copepods and small cladocerans, and a major grazer is missing. This niche was occupied by a Daphnia species, which disappeared as a result of the introduction of the planktivorous sardine Limnothrissa miodon (Dumont 1986). The hypothesis of low trophic efficiency in Lake Kivu might result from zoo- and phytoplankton structure, an might explain why fish yield is low in this lake, when compared to other systems where the Tanganyika sardine was introduced (RoEST 1999). The fate of primary production not grazed by the mesozooplankton is to fuel the microbial food web in the mixolimnion, or to settle to the anoxic zone and to the lake sediment.

\section{Acknowledgements}

Hugo Sarmento benefited from a King Léopold III Fund for Nature Exploration and Conservation grant for one mission in August 2003. The Foundation to Promote Scientific Research in Africa financed another mission in February 2004. Mwapu Isumbisho held a PhD grant from the BTC-CTB (Coopération Technique Belge, Belgium) and the IFS (International Foundation for Science). The ECOSYKI project and the International Association of Theoretical and Applied Limnology (SIL) financed the field work. We are grateful to Boniface Kaningini, Georges Alunga and Pascal Masilya for field and laboratory assistance.

\section{References}

Collart, A. 1954. La pêche au Ndagala au lac Tanganyika. Bull. Agric. Congo Belge 45: 3-49.

Degens, E., R.P. Herzen, H.-K. Wong, W.G., Deuser \& H.W. JANNASCH. 1973. Lake Kivu: Structure, chemistry and biology of an East African Rift lake. Geol. Rundsch. 62: 245277.

DESCY, J.-P. 1990. Etude de la production planctonique au lac Kivu - Rapport de mission, Projet PNUD/FAO - RWA/87/012. UNECED, Namur.

Descy, J.-P., M.-A. Hardy, S. Stenuite, S. Pirlot, B. LeporcQ, I. Kimirei, B. Sekadende, S.R. Mwaitega \& D. Sinyenza. 2005. Phytoplankton pigments and community composition in Lake Tanganyika. Freshw. Biol. 50: 668-684.

Dumont, H.J. 1986. The Tanganyika sardine in Lake Kivu: another ecodisaster for Africa? Environ. Conserv. 13: 143148.

GuILDFORD, S.J. \& R.E. Hecky. 2000. Total nitrogen, total phosphorus, and nutrient limitation in lakes and oceans: Is there a common relationship? Limnol. Oceanogr. 45: 1213-1223.

Guildford, S.J., R.E. Hecky, W.D. Taylor, R. Mugidde \& H.A. Boотsмa. 2003. Nutrient enrichment experiments in tropical great lakes Malawi/Nyasa and Victoria. J. Gt. Lakes Res. 29: 89-106.

Guildford, S.J., H.A. Bootsma, W.D. Taylor \& R.E. Hecky. 2007. High variability of phytoplankton photosynthesis in response to environmental forcing in oligotrophic Lake Malawi/Nyasa. J. Gt. Lakes Res. 33: 170-185.

Healey, F.P. 1975. Physiological indicators of nutrient deficiency in algae. Fish. Mar. Serv. Res. Div. Tech. Rep. 585: 30.

Isumbisho, M., H. Sarmento, B. Kaningini, J.C. Micha \& J.P. DesCy. 2006. Zooplankton of Lake Kivu, East Africa, half a century after the Tanganyika sardine introduction. J. Plankton Res. 28: 971-989.

JANNASCH, H.W. 1975. Methane oxidation in Lake Kivu (central Africa). Limnol. Oceanogr. 20: 860-864.

KIRK, J. 1983. Light and photosynthesis in aquatic ecosystems. Cambridge University Press.

Roest, F.C. 1999. Introduction of a pelagic fish into a large natural Lake : Lake Kivu, Central Africa, p. 327-338. In 
W.L.T. van Densen \& M.J. Morris [eds], Fish and fisheries of Lakes and reservoirs in Southeast Asia and Africa. Westbury Publishing, Otley.

Sarmento, H., M. Isumbisho \& J.P. Descy. 2006. Phytoplankton ecology of Lake Kivu (eastern Africa). J. Plankton Res. 28: $815-829$.

Sarmento, H., M. Leitao, M. Stoyneva, A. Couté, P. Compère, M. Isumbisho \& J.-P. Descy. 2007. Diversity of pelagic algae of Lake Kivu (East Africa). Cryptogam. Algol. 28: 245269.

Sarmento, H., F. Unrein, M. Isumbisho, S. Stenuite, J.M. GASOL \& J.P. Descy. 2008. Abundance and distribution of picoplankton in tropical, oligotrophic Lake Kivu, eastern Africa. Freshw. Biol. 53: 756-771.

Schmid, M., M. Halbwachs, B. Wehrli \& A. Wüest. 2005. Weak mixing in Lake Kivu: New insights indicate increasing risk of uncontrolled gas eruption. Geochem. Geophy. Geosy. 6: 1-11 (doi:10.1029/2004GC000892).

SimberlofF, D. 1995. Why do introduced species appear to devastate islands more than mainland areas? Pac. Sci. 49: 87-97.
SILSBE, G.M. 2004. Phytoplankton production in Lake Victoria, East Africa. M.S. thesis, University of Manitoba, Canada.

Steeman-Nielsen, E. 1952. The use of radio-active carbon $\left({ }^{14} \mathrm{C}\right)$ for measuring organic production in the sea. J. Cons. Perm. Int. Expl. Mer. 18: 117-140.

Stenuite, S., S. Pirlot,M.-A. Hardy, H. Sarmento, A.-L. Tarbe, B. Leporce \& J.P. Descy. 2007. Phytoplankton production and growth rate in Lake Tanganyika: evidence of a decline in primary productivity in recent decades. Freshw. Biol. 52: 2226-2239.

Tietze, K., M. Geyh, H. Müller, L. Schröder, W. Stahl \& H. WeHner. 1980. The genesis of the methane in the lake Kivu (Central Africa). Geol. Rundsch. 69: 452-472.

VAlDERRAmA, J.C. 1981. The simultaneous analysis of total nitrogen and total phosphorus in natural waters. Mar. Chem. 10: $109-122$

VolLENWEIDER, R.A. 1974. A manual on methods for measuring primary production in aquatic environments. IBP Handook, v.12, 2nd ed. Blackwell Scientific.

Authors' addresses: H. Sarmento, M. Isumbisho, S. Stenuite, F. Darchambeau, B. Leporcq, J.-P. Descy, Laboratory of Freshwater Ecology, URBO, Department of Biology, University of Namur, B-5000 Namur, Belgium. E-mail: hugo.sarmento@gmail.com. M. Isumbisho, Unité d'Enseignement et de Recherche en Hydrobiologie Appliquée (UERHA), ISP/Bukavu, B.P. 854-Bukavu, Democratic Republic of Congo 